\title{
FEDERAL INCOME TAXATION: DEDUCTIBILITY OF TRAVELING EXPENSES AND THE OVERNIGHT RULE
}

As A GENERAL RULE taxpayers may not deduct personal, living, and
family expenses in determining adjusted gross income. ${ }^{1}$ However, Sec-
tion I62 of the Internal Revenue Code of 1954 permits the deduction
of meal and lodging costs ${ }^{2}$ while traveling "in pursuit of trade or
business. . ." In order to be deductible, ${ }^{4}$ these traveling expenses
must be incurred while away from the taxpayer's principal place of
business, his "tax home." In addition, the Treasury regulations require

1 "Except as otherwise expressly provided in this chapter, no deduction shall be allowed for personal, living, or family expenses." INr. REv. CODE OF 1954, $\S 262.4$ Mertens, Federal INCOME Taxation $\$ \S 25.17,25.99$ (Rev. ed. 1960).

${ }^{2} \mathrm{Meal}$ and lodging costs are considered traveling expenses under the 1954 Code, $\S_{162}(a)(2)$, whereas transportation expenses are limited to costs such as gas and oil, plane, train, bus, and boat fares. See S. REP. No. 1622, 83d Cong., 2d Sess. 168, 169 (1954); T.D. 3 IOI, 22 TREAS. DEC. INT. REv. 545 (1920). Transportation expenses need not be incurred away from home to be deductible. INT. REv. CoDE of 1954, \$6z(z)(C); INT. Rev. Serv. U.S. Dept. OF Treasury, Pub. No. 300, Deductions FOR TRAVELING AND TRANSPORTATION EXPENSES 2 (1956). The cost of commuting between the residence and the principal place of business, however, is not deductible. See note 5 infra.

" "There shall be allowed as a deduction all the ordinary and necessary expenses paid or incurred during the taxable year in carrying on any trade or business, including- ... (2) traveling expenses (including the entire amount expended for meals and lodging) while away from home in the pursuit of a trade or business . ..." INT. REV. CODE OF 1954, § 162 (a) (2).

'A taxpayer may deduct traveling expenses from his gross income in determining adjusted gross income. INT. REv. CODE OF 1954, §62(2)(B). Because of this he can still elect to take the standard $10 \%$ deduction under $\S 144$ without itemizing his other deductions. INT. Rev. CODE OF 1954, § 63. See Kenneth Waters, 12 T.C. 414 (1949).

"The "tax home" concept was introduced by judicial construction of the phrase "away from home" found in the statute. Peurifoy v. Commissioner, 358 U.S. 59 (1958) ; Commissioner v. Flowers, 326 U.S. 465 (1946); Allan Cunningham, 22 T.C. 906 (1954); Michael J. Carroll, 20 T.C. 382 (1953); Walter M. Priddy, 43 B.T.A. 18 (1940); Charles E. Duncan, 17 B.T.A. 1088 (1929); Mort L. Bixler, 5 B.T.A. $1181(1927)$. The Commissioner has acquiesced in this construction of the statute. Rev. Rul. 56-49, 1956-1 Cum. Bull. 152; Rev. Rul. 55-604, 1955-2 Cum. Burl. 49; Rev. Rul. 54-497, 1954-2 Cum. Bull. 75. See 4 Mertens, Federal Income TaxaTION § 25.93 (Rev. ed. 1960).

One is not away from his tax home unless he is out of the general locality. Rev. Rul. 56-49, 1956-I Cum. Bunl. 152. The tax home concept thus bars the deduction of commuting expenses from residence to place of business. See Chandler v. Commissioner, 226 F.2d 467 (1st Cir. 1955); Beatrice H. Albert, 13 T.C. 129 (1949) and 15 T.C. 350 (1950); Treas. Reg. \& x.162-2(e) (1958). Where a taxpayer does not maintain a permanent residence he may not deduct lodging costs as traveling expenses. See Charles G. Gustafson, 3 T.C. 998 (1944); Herman Martin, 44 B.T.A. 185 (1941). 
that the expenses be incurred on an overnight trip. ${ }^{\circ}$ Under this rule the entire cost of meals and lodging is deductible on business trips if the taxpayer is gone overnight, but no part of either expense may be deducted if he returns the same day. ${ }^{7}$ This overnight rule has been repeatedly questioned and limited. ${ }^{8}$ In one recent case the overnight rule was further modified, and in another decision was completely rejected. ${ }^{10}$

In Williams v. Patterson, 11 the taxpayer, a railroad conductor, worked a sixteen to eighteen-hour day, every other day, on a run between Montgomery, Alabama, his tax home, and Atlanta, Georgia. He had a six hour lay-over in Atlanta where he ate and slept or rested in a small hotel room before returning to Montgomery, arriving the same day. ${ }^{12}$ The Court of Appeals for the Fifth Circuit, reversing the district court, held the cost of meals, lodging, and tips during the lay-over deductible. Purporting to reject the overnight rule, the court reasoned that the test should be whether the taxpayer's employment required

See generally Haddleton, Traveling Expenses "Away From Home," i TAx L. REv. 261 (1962); Note, Travel Expense Deductions, 43 VA. L. REv. 59 (1957).

- Treas. Reg. $\$ \S 1.162-17$ (b) (3)(ii), 1.162-17(b) (4), 1.162-17(c)(2) (1958). These are the first regulations to include the overnight rule. Evidently the rule first appeared in 1946 Your Federal INCOME TAX 45. Kenneth Waters, 12 T.C. 414 (1949).

'INT. Rev. Serv. U.S. Dept. of Treasury, Pub. No. 300, Deductions for Traveling and Transportatton Expenses (1956).

'Most previous cases rejecting the overnight rule dealt only with transportation expenses. Chandler v. Commissioner, 226 F.2d 467 (1st Cir. 1955); Scott V. Kelm, 110 F. Supp. 8Ig (D. Minn. 1953); Horace E. Podems, 24 T.C. 21 (1955); Kenneth Waters, 12 T.C. 414 (1949). See also note 2 supra.

Some cases, however, have followed the rule. See Al J. Smith, 33 T.C. 861 (1960) (meals); Fred Marion Osteen, 14 T.C. 126x (1950) (meals).

In 1940, prior to the inception of the overnight rule, the Commissioner ruled that "locomotive engineers and other railroad trainmen, who are required to remain at awayfrom-home terminals in order to obtain necessary rest prior to nnaking a further run or beginning a return run to the home terminal, are entitled to deduct for Federal income tax purposes the cost of room rental and meals while away from home on such runs." L.T. 3395, I940-2 Cum. Burl. 64. (Emphasis added.) In David G. Anderson, 8 T.C. 649 (1952), the court held that ineals were deductible in this situation, and rejected the overnight rule. The Commissioner acquiesced in the Anderson case, 1952-2 CuM. Bull. 1, and adopted the holding in Rev. Rul. 54-497, 1954-2 CuM. Bull. 75, 79.

However, when the overnight rule was added to the regulations, the above exception was not included. See note 6 supra.

-Williams v. Patterson, 286 F.2d 333 (5th Cir. 1961).

${ }^{10}$ Hanson v. Commissioner, 298 F.2d 391 (8th Cir. 1962).

${ }_{212} 28$ F.2d $333 \cdot$ (sth Cir. $196 x$ ).

12 Id. at 334. 
him to "be released from work to obtain necessary sleep or rest. . . ."18 The Treasury has acquiesced in this decision, viewing it as a reasonable modification of the overnight rule. ${ }^{14}$

In a more recent case, Hanson v. Commissioner, ${ }^{15}$ the Eighth $\mathrm{Cir}$ cuit also refused to apply the overnight rule, but adopted a different approach from that taken by the Fifth Circuit in the Williams case. The petitioner was the sole executive of a construction company located in Washington, Iowa, petitioner's tax home. Petitioner traveled extensively in supervising each of the company's jobs. At times he would return home at night, and on other occasions would spend the night away. ${ }^{16}$ The Commissioner refused to allow the cost of meals away from home when the petitioner returned home at night. The Court of Appeals, reversing the Tax Court, ${ }^{17}$ held that the expense of petitioner's meals was deductible regardless of whether he was away from home overnight. In reaching this result the court rejected the overnight rule and stated that the only test authorized by the statute was whether petitioner was "away from home."18

The Revenue Act of 1918 allowed only the deduction of "ordinary and necessary" business expenses. ${ }^{18}$ Under this provision the Treasury initially denied the deduction of meals and lodging expenses incurred on business trips. ${ }^{20}$ In 1920 the Treasury changed its position and allowed deduction of the cost of meals and lodging "in excess of any expenditures ordinarily required for such purposes when at home."21 This rule allowed the deduction of traveling expenses properly attributable to business and still maintained the non-deductible status of "personal" expenses.

\footnotetext{
${ }^{18}$ Id. at 338, quoting Sam J. Herrin, 28 T.C. 1303,1305 (1957).

${ }^{16}$ Rev. Rul. 61-221, 1961 INT. Rev. BULL. No. 52, at 6. The Williams case was specifically approved, but the ruling continued: "However, the Service does not consider the brief interval during which an employee may be released from duty for the purpose of eating rather than sleeping as constituting an adequate rest period to satisfy the "overnight" rule as a test for the deductibility of meal expenses on business trips completed within one day."

${ }_{10} 298$ F.2d 391 (8th Cir. 1962).

${ }^{10}$ Id. at 393 .

${ }^{17} 35$ T.C. $413(\times 960)$.

18 "For tax purposes, the petitioner's home was Washington, Iowa. Any travel on business away from the area of Washington, Iowa, was travel away from home within the meaning of the statute, whether such travel involved remaining overnight or not." 298 F.2d at 397 .

${ }^{10}$ Rev. Act of $1918, \S 2 \times 4$ (a) (I), 4o Stat. ro66.

${ }^{90}$ U.S. Treas. Reg. 45, art. 292, 2 I TReas. Dec. INT. Rev. 24 I (1919).

11 T.D. 3 ror, 22 TREAs. DEC. INT. REv. 545 (1920).
} 
However, Section 214(a)(I) of the Revenue Act of I92I made the entire cost of meals and lodging deductible "while away from home in the pursuit of a trade or business."22 The express purpose of this provision was to aid traveling salesmen. ${ }^{23}$ Section $2 \mathrm{I}_{4}(\mathrm{a})(\mathrm{I})$ has been carried over, in substantially the same form, into Section $I 62(a)(2)$ of the 1954 Code. $^{24}$

To the 1954 Code's treatment of traveling expenses the Treasury has appended the arbitrary overnight rule. ${ }^{25}$ Perhaps this requirement may be justified as a rule to determine the reasonableness of incurring lodging expenses. There are, however, occasional situations where, as the Williams case demonstrates, lodging expenses may be reasonably incurred on non-overnight trips. ${ }^{26}$ Thus the overnight rule is not always suitable as a test for the reasonableness of lodging expenses. More clearly, as was pointed out in Hanson, the statute gives no justification for the rule insofar as it bars the deduction of meals, since this expense is wholly unrelated to whether a traveler is away overnight. ${ }^{27}$

In creating the travel expense deduction Congress undoubtedly felt that the cost of personal expenses on trips is greater than at home. ${ }^{28}$ This extra amount may properly be thought of as a business expense. In allowing the deductibility of the entire cost of food and lodging on trips away from home, however, Congress made a distinction in favor of the business traveler, ${ }^{2 \theta}$ since he may deduct personal expenses ${ }^{30}$ as well

${ }^{22}$ Rev. Act of $1921, \$ 214(\mathrm{a})(1), 42$ Stat. 239.

${ }^{28}$ See 6I CoNG. REC. 5201, 6673 (1921).

"See note 3 supra.

${ }^{28}$ See note 6 supra.

${ }^{26}$ For example, a lawyer who travels to argue a case should be justified in deducting the cost of a room necessary to allow him to clean up, change clothes, and prepare for his case, even though he returns home that day.

${ }^{27} 298$ F.2d 391 (8th Cir. 1962).

"There is nothing in the legislative history of the travel expense deduction provisions ... to show that Congress intended any such special interpretation as the overnight rule of the words 'travel ... while away from home. . . ' Surely it would be absurd to say that an employee who flies from Boston to Washington on business and returns to Boston on the same day is not entitled to the deduction, but that if he takes two days for the whole trip he is entitled to the deduction." Kenneth Waters, 12 T.C. 414, 416-17 (1949). See generally Haddleton, Traveling Expenses "Away From Home," I 7 TAX L. REV. 261 (1962).

"This reasoning is implicit in the "tax home" concept. See note 5 supra. This is justified by the notion that unfamiliar surroundings, in part at least, give rise to the added expenses.

${ }^{20}$ See notes 22 \& 23 supra.

Since the entire cost of meals is allowed, the amount the taxpayer would spend at home, ordinarily a "personal" expense, becomes deductible, as well as the excess. This 
as those necessitated by business trips. ${ }^{31}$ Thus, the overnight rule does not merely discriminate between overnight and daytime travelers by allowing the former a deduction for personal expenses, but also by denying the latter a deduction for expenditures properly considered a business expense-the extra amount spent on trips. ${ }^{32}$ This discriminatory operation of the overnight rule far outweighs its possible utility as a convenient method of determining the allowability of travel expenses.

In refusing to follow the overnight rule, both the Williams and Hanson decisions sacrificed the convenience of a "rule of thumb" for a more just result. However, in altering the rule to a test of "necessary sleep or rest," ${ }^{33}$ the court in the Williams case merely created another unjustified yardstick, ${ }^{34}$ substantially similar in operation to the rule

discrimination is not usually present in lodging expenses, since this is an entirely additional expense to the taxpayer who maintains a residence. The taxpayer who does not maintain a permanent residence may not deduct lodging expenses, on the theory that he is never "away from home." James v. United States, I76 F.Supp. 270 (D. Nev. 1959); see Charles G. Gustafson, 3 T.C. 998 (1944); Herman Martin, 44 B.T.A. 185 (1941). While this conflicts with the concept that the tax home is the principal place of business, see note 5 supra, it is justified on the ground that it places these taxpayers on the same basis as those who maintain residences. See 4 MERTENs, FEderal Income Taxation $\$ 25.93$ (Rev. ed. 1960). See generally Haddleton, Traveling Expenses " $A$ way From Home," I 7 Tax L. Rev. 261 (1962).

so INT. Rev. CoDe of 1954, § 262. The cost of meals for business entertainment, as an example, has been disallowed where it did not exceed that amount ordinarily spent as a personal expense. Richard A. Sutter, 21 T.C. I 70 (1953).

${ }^{31}$ This discriminatory treatment, however, may be justified on several practical grounds. I) Merely allowing the excess would result in increased bookkeeping and enforcement problems. 2) Generally only meals are subject to the "ordinary-excess" analysis, since the entire cost of lodging is deductible if a permanent residence is maintained. See note 5 supra. 3) Even the "excess" concept is vulnerable inasmuch as all or part of this amount may often be attributable to the whim and caprice of the taxpayer. Once reasonably incurred, expenses do not appear to be attacked on the grounds that they are excessive.

For these reasons, while the rule under the 1918 Revenue Act, as construed by the Treasury in 1920, may more nearly comport with the general policy of refusing deductions for personal expenses, see note 30 supro, a return to that rule is not urged. See notes 19 \& 21 supra.

${ }^{2}$ See note 28 supra.

286 F.2d 333,338 ( 5 th Cir. 1961 ).

"See note 27 supra. The court in Hanson v. Commissioner, 298 F.2d 391, 395 (8th Cir. 1962), observed that several "tests" had been evolved by courts seeking to escape the operation of the overnight rule, citing Williams v. Patterson, 286 F.2d 333 (5th Cir. 1961); Horace E. Podems, 24 T.C. 21 (1955); Charles H. Hyslope, 2 I T.C. I31 (1953); Joseph M. Winn, 32 T.C. 220 (1959), as examples of tests unwarranted by the terms of the statute. 
thought to be rejected..$^{35}$ The Hanson case, ${ }^{38}$ on the other hand, must be approved for entirely rejecting the application of the overnight rule to the cost of business trip meals. Within the framework of section I62(a) (2), the Hanson decision is to be commended as a reasonable interpretation of the statutory language.

\footnotetext{
See note 14 supra.

${ }^{20} 298$ F.2d 39 r (8th Cir. 1962). See note 28 suppra.
} 